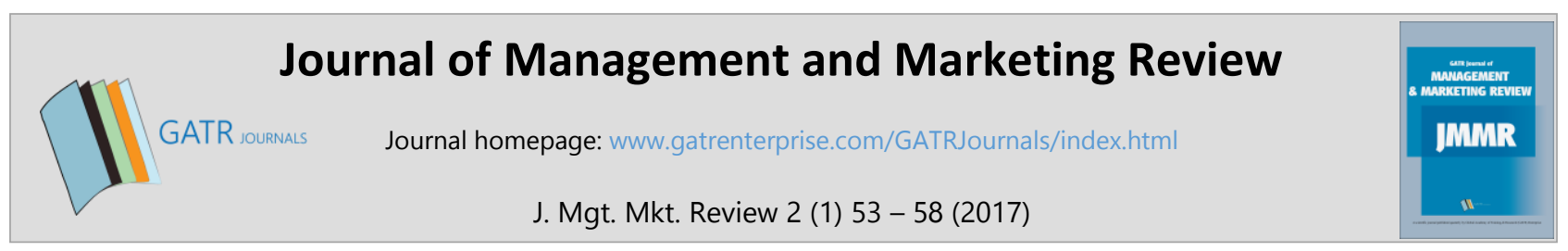

\title{
Green Marketing vs. Greenwashing. How to protect against Negative Impact of Greenwashing?
}

\author{
Margareta Nadanyiova ${ }^{1 *}$ and Jana Kliestikova ${ }^{2}$ \\ ${ }^{1,2}$ University of Zilina, Faculty of Operation and Economics of Transport and Communications, Univerzitna 1, 01026 Zilina, Slovak \\ Republic
}

\begin{abstract}
Objective - Following paper deals with the essence of green marketing, green consumers and green strategies. It also defines greenwashing, different types of greenwashing, the seven sins of greenwashing, greenwashing index and negative impact of greenwashing. Based on this are outlined measures to protect against negative impact of greenwashing.

Methodology/Technique - The study carried out with reviewing literature.

Findings - The ways to avert the negative impacts of greenwashing includes: increasing awareness through media and education, elimination of greenwashing by companies, inclusion of greenwashing into the legislation, blacklisting of companies using greenwashing

Novelty - The study suggests solutions for negative impacts of greenwashing.

Type of Paper: Review
\end{abstract}

Keywords: Green Marketing; Greenwashing; Eco-friendly; Social Responsibility; Environment.

JEL Classification: D11, E21, M31.

\section{Introduction}

Currently, many companies are oriented not only to the pursuit of profit. Their priority is especially customer and his needs, even whole environment. They know that essence of business success lies in the responsible approach to entrepreneurship. Smart company focuses its goals not only to economical way but it also includes environmental and social points of its entrepreneurial activity.

Thus it is clear, that problem regarding environmental and its protection belongs to the highly discussed topics. The standard of living is gradually increasing therefore creating correct ecological environment should now be obvious to everyone. However, many companies use the growing importance of the environment to their advantage, they create a false picture and image of the company and products. Large number of companies

\footnotetext{
Paper Info: Received: January 22, 2017

Accepted: March 18, 2017

* Corresponding author:

E-mail: margareta.nadanyiova@fpedas.uniza.sk

Affiliation: Faculty of Operation and Economics of Transport and Communications, University of Zilina,

Slovak Republic
} 
has a history of green consumers' interests and they are trying to divert attention through green PR and promotion, regulation and denial of the impact of its activities and products (Ottman, 2011).

\section{The difference between green marketing and greenwashing}

So how can we recognize that the behavior of the company is truly eco-friendly, or it is only the effort to mislead the consumer, so called "greenwashing"?

While in the world's media is the wave of greenwashing just the new phenomenon, itself is not at all. Many companies look like eco-friendly but the reality is different. They misuse the tools of marketing communication, especially advertisement, with the effort to present their products as "green", "bio" or "organic". Often, however, it is just the misleading the consumers and administration of fraudulent information about products and also about company. This results in mistrust and skepticism people towards idea and use of green marketing.

\subsection{The essence of green marketing}

According to The American Marketing Association (2016), "green marketing is the marketing of products that are presumed to be environmentally safe." The social definition says that green marketing is "the development and marketing of products designed to minimize negative effects on the physical environment or to improve its quality" and the environmental viewpoint presents it as "the efforts by organizations to produce, promote, package, and reclaim products in a manner that is sensitive or responsive to ecological concerns."

Currently, we can find much more definitions of this term conceived by marketing specialists and researchers, some of them are not fully recognized. But all definitions agree with the fact, that green marketing is a holistic and responsible approach, which includes identifying, forecasting and seeking opportunities to satisfy needs of stakeholders (in generally) without any negatively impacts on the society and environment (Rypakova and Krizanova, 2013).

Due to issues of environmental protection, it was created a new steadily growing segment so called "green consumers". This segment is characterized by ignoring the products that endanger the health, participate in the destruction of the environment during production, use, disposing, or they are a source of excessive waste and so on. Psychographic segmentation created for the American market by institutions Natural Marketing Institute divides consumers into five groups (Ottman, 2011):

1. LOHAS (Lifestyles of health and sustainability).

2. Naturalists - consumers are primarily focused on healthy lifestyles.

3. Drifters - consumers are more influenced by social trends such as personal values.

4. Conventionals - practical consumers who are mainly motivated by saving money.

5. Unconcerneds - segment indifferent to environmental protection.

To determine the appropriate green marketing strategy for the companies, it is necessary to know the target segment perfectly. It means to know its habits, preferences and all other factors influencing the buying behavior. According to Ginsberg and Bloom (2004), it is necessary for managers to answer two basic questions before selecting a specific strategy of green marketing. First, "how important is segment of green consumers for our company?" And the second, "can the brand or company be different across the green dimension?" Based on this the company can choose from the following strategies:

- Lean Green - companies are responsible to society, but their main goal is not to present their ecofriendly initiative or green properties of their products. The main interest is to reduce costs and increase efficiency through activities on the environment. 
- Defensive Green - companies are using green marketing as a preventive way in the state of emergency or in the fight against competition. They improve their image and they are aware that the green consumers are crucial for them due the profit.

- Shaded Green - companies are investing in environmentally friendly long-term processes that requires the considerable financial but also non-financial resources. They take the opportunity to innovate its products and technologies that could guarantee them a competitive advantage.

- Extreme Green - companies fully integrate environmental issues into business processes and company's products, e.g. through specialized outlets and distribution.

\subsection{Greenwashing and its negative impacts}

The very concept of greenwashing comes from the term "whitewashing" that can be understood as a concerted effort to mask uncomfortable facts, most often in politics (EnviroMedia Social Marketing, 2016). Therefore the greenwashing means and also assumes the same as whitewashing, but from an environmental point of view, namely misleading consumers and the public opinion. Companies have a tendency to promote themselves and their products as a responsible and friendly to the environment and try to notify customers of their better impact on the environment, although this is not entirely true (Hernik, 2014), (Rahman, Park and Chi 2015), (Willness, Zerr and Jones, 2012).

According to Grant (2007), greenwashing means "doing something normal to make it look greener." He further develops and maintains his theory that greenwashing relates to particular companies, which have tendency to promote their products as natural, while their products are only genetically modified or containing added antibiotics.

In the past the greenwashing was limited to solve problems of deception of the public opinion through advertising. As time it began to develop and exist in other areas, such as in advertising, and with it were joined many other accusations relating to greenwashing (Bowen and Aragon-Correa, 2014), (Marquis, Toffel and Zhou, 2016). Today, in addition to advertising it deals with a wide range of business activities such as the issuing of various environmental reports, educational programs, organizing and sponsoring events. Regardless of where and in what form greenwashing occurs, it is always a form of misleading the consumer and public opinion by rendering the company as having positive impact, that makes all its actions with due consideration for the environment with the aim of continuous improvement (Nyilasy, Gangadharbatla and Paladino, 2014). The global non-profit organization BSR defines four types of greenwashing (Horiuchi, 2009):

1. Misguided greenwashing. This category includes companies, that are making significant efforts to be more environmentally-friendly. Their effort is not very effective and they often use claims such as "environmentally friendly" in their communication.

2. Unsubstantiated greenwashing. In this category are companies in which at first glance it seems that they do their job commendably and they provide their arguments based on substantiated data. But after a closer examination it reveals that companies have not made this move for the environment, but for their own benefit.

3. Greenwash noise. It includes the companies, who say they are "green" while they have not sufficiently substantiated their arguments. The actual corporate statements are not convincing even for customers.

4. Effective environmental communication. And just this group represents the model for all organizations, because they do everything for improving environmental and social performance over different functions in the company and they are able to communicate effectively.

Over the last years we can observe a large increase in cases of greenwashing. Canadian company Terra Choice based on research developed and categorized false and misleading claims about the environment into 7 categories, such as "The seven sins of greenwashing" (Terra Choice, 2009), (Horiuchi, 2009): 
- Sin of the hidden trade-off. A contention that the product is "green" leaning on a few facts that are unrelated to environmental protection.

- Sin of no proof. A contention about eco-friendly properties is not scientifically proven or certificated.

- Sin of vagueness. A contention is bad defined and probably consumers will understand incorrect.

- Sin of worshiping false labels. The product is marked with fake labels, words or images.

- Sin of irrelevance. A contention about eco-friendly properties is true but it is absolutely unimportant for consumers.

- Sin of lesser of two evils. A contention is true within the product category, but that risks distracting the consumer from the greater environmental impacts of the category as a whole.

- Sin of fibbing. Environmental contentions that are simply false.

\section{Protection against negative impact of greenwashing}

So, in which cases can we talk about greenwashing? As an example we can give several risk areas where sellers through advertising gimmick and misinformation are seeking to impose consumers the view that their products are environmentally friendly. In fact, they just offer needlessly, wasteful or non-renewable products that seem to be "green" or environmentally friendly:

- Paper towels made partly or entirely from recycled materials that are completely uneconomic.

- Compostable disposable tableware, having high transport and manufacturing costs.

- Water bottles, for which the manufacturers are trying to lure the lower amount of plastic that however the eco products should not contain at all.

- Biofuel from ethanol produced from corn, its production also requires a gallon of oil.

- Products for household cleaning, for which consumers should give the greatest attention in particular to the ambiguous statements (eco-friendly, bio, organic, ecological).

- Products and toys for children, which although not contain dangerous substances - Bisphenol A (BPA), but which instead manufacturers use a variety of other less known compounds that also may be dangerous.

- Electronics, which contains a false indication or they completely lacking.

- Products so-called "do it yourself" highlighting the various benefits that should be associated with air quality, recycling, or energy.

On the market, there are many products and if consumers want to buy only products that are eco-friendly, they should check and verify that these products do not tending to one of the signs of greenwashing. Of course, it is not always easy to verify directly whether the products are suitable, or it is just plain greenwashing. The company Terra Choice (2010) in its research claims that it is more appropriate when buying used specialized stores (organic shop) or the retail market, the so-called "big box stores" that are more closely monitored and investigated by media and their share of greenwashing products ranges at around 5,6\% for retailers and 0,5\% for specialized retail stores.

For protection of consumers against negative effects of greenwashing is also used so-called Greenwashing Index. Greenwashing Index is an online portal that enables all consumers to publish advertisements that may contain greenwashing elements. Subsequently others consumers can read that ad, write comments and subjectively evaluate according to their gravity. This site asks consumers to raise awareness about misleading green advertising, gradually helps to eliminate negative impact of greenwashing and avoids to misleading of public opinion. Greenwashing Index is an automated tool that records the responses to five statements on the relevance of marketing claims in advertisements (EnviroMedia Social Marketing, 2016):

1. The advertisement misleads with words. 
2. The advertisement misleads with visuals or graphics - usage "green" images due to make the consumer believe that products and organization are eco-friendly.

3. The advertisement makes a "green" claim that is vague or seemingly unprovable.

4. The advertisement overstates or exaggerates how "green" the product, company or service actually is.

5. The advertisement hides or masks important information due making the "green" claim.

The goal of Greenwashing Index is mainly to learn consumers understand an advertisement and recognize if what they are seeing is greenwashing or not. It also includes creation of better-informed public, to manufacturers can not deceive about using principles of green marketing and social responsibility (EnviroMedia Social Marketing, 2016).

Way how to avert the negative impacts of greenwashing includes also the following solutions:

- Increasing awareness about greenwashing through the media (Internet, Social networks, TV and so on);

- Increasing awareness about greenwashing during education;

- Elimination of greenwashing by companies;

- The inclusion of greenwashing into the legislation;

- The black list of companies using greenwashing.

\section{Acknowledgements}

The paper is a partial output of scientific grant "The fundamental research perception of corporate social responsibility as a value for customer" (Grant No. VEGA 1/0024/15) and a partial output of institutional research "The analysis of the impact of companies' green marketing activities on Slovak consumers" (No. $1 / \mathrm{KE} / 2016)$.

\section{References}

American Marketing Association (2016). Green marketing. In Dictionary. Retrieved from http://www.marketingpower.com/_layouts/dictionary.aspx

Bowen, F. \& Aragon-Correa, J.A. (2014). Greenwashing in Corporate Environmentalism Research and Practice: The Importance of What We Say and Do. Organizations \& Environment, 27(2), 107-112.

EnviroMedia Social Marketing and the University of Oregon (2016). About Greenwashing. In Greenwashing Index. Retrieved June 15, 2016, from http://greenwashingindex.com/about-greenwashing/

Grant, J. (2007). The green marketing manifesto. Chichester: John Wiley \& Sons.

Hernik, J. (2014). Greenwashing - essence and analysis on chosen example. In International Scientific Conference on Economic Science for Rural Development (p. 25-32). Jelgava, Latvia.

Horiuchi, R. (2009). Understanding and Preventing Greenwash: A Business Guide. Place of publication: Business for Social responsibility. Retrieved from http://www.bsr.org/en/our-insights/report-view/understanding-andpreventing-greenwash-a-business-guide

Marquis, C., Toffel, M. \& Zhou, Y. (2016). Scrutiny, Norms, and Selective Disclosure: A Global Study of Greenwashing. Organization Science, 27(2), 483-504.

Nyilasy, G., Gangadharbatla, H. \& Paladino, A. (2014). Perceived Greenwashing: The Interactive Effects of Green Advertising and Corporate Environmental Performance on Consumer Reactions. Journal of Business Ethics, 125(4), 693-707.

Ottman, J. (2011). The new rules of green marketing: Strategies, tools and inspiration for sustainable branding. San Francisco: Berrett-Koehler Publ.

Rahman, I., Park, J. and Chi, CGQ. (2015). Consequences of "greenwashing": consumers' reactions to hotels' green initiatives. International Journal of Contemporary Hospitality Management, 27(6), 1054-1081.

Rypakova, M. \& Krizanova, A. (2013). The concept of CSR and green marketing as a major source of price competitiveness. In Faktory prosperity podnikư v lokálním a globálním prostředí optikou roku 2013(pp. 521-530). Praha: Oeconomica. 
Terra Choice (2010). Greenwashing Report 2010. Retrieved June 16, 2016, from http://sinsofgreenwashing.com/index35c6.pdf

Terra Choice (2009). The Seven Sins. Retrieved June 16, 2016, from http://sinsofgreenwashing.com/findings/the-sevensins/index.html

Willness, C., Zerr, K. and Jones, D. (2012). How awareness, greenwashing, and public opinion influence employees' concept of their company's "green" practices. International Journal of Psychology, 47(1, SI), 527-527. 